\title{
OSMAN BÜLENT MANAV'A VE ŞIIIRLERINNE DAİR
}

\section{Harun SAHIN*}

Geliş Tarihi: Nisan, 2016

Kabul Tarihi: Haziran, 2016

\section{$\ddot{O} z$}

Osman Bülent Manav, hekim olmasına rağmen şiire gönül vermiş çağdaş Türk şairlerinden biridir. İki şiir kitabı yayımlanmıştır. Ailesinin şiire olan ilgisi, onun yetişmesinde etkili olmuştur.

Bu makalede şairin 76 şiiri, şekil özelliklerin yanı sıra, muhteva özellikleri bakımından da incelenmiştir. Şair, toplumsal konuların yanı sıra, din, tasavvuf, aşk ve gurbet konularında şiirler yazmıştır.

Osman Bülent Manav’ın şiirlerinde, insan hâl ve hareketleriyle tabiat arasında bir bağ kurulur. Ona göre "vatan namustur"; ama vatan ve millet sevgisi aleni bir hamaset ile değil, ince bir hissî duyarlılıkla karşımıza çıkar. Şair iki mekânın tesiri altındadır: İstanbul ve yayla.

Anahtar Sözcükler: Osman Bülent Manav, Yarpız Kokulu Şiirler, Musandıra, şekil ve muhteva, dil ve üslup.

\section{ABOUT OSMAN BÜLENT MANAV AND HIS POETRY}

\begin{abstract}
Osman Bülent Manav, who sets his heart on poetry despite being a doctor, is one of the important modern Turkish poets. He is the author of two books of poetry. His family's interest in poetry have been effective in his upbringing.

76 poems of the poet has been analyzed in terms of form and content features in this article. The poet has written poems on religious-sufistic, love and homesickness issues besides social ones.

There is a connection between nature and people's behaviours-manners in the poems of Osman Bülent Manav. He assumes homeland as honor; but patriotism appears as a sentimental sensibility not with a clear heroism. The poet is under heavy impact of two places: İstanbul and highland.
\end{abstract}

Keywords: Osman Bülent Manav, Yarpız Kokulu Şiirler, Musandıra form and content, language and style.

\section{Osman Bülent Manav'ın Hayatı ve Ailesi}

Asıl adı Bülent Manav'dır. 1970 yılının Temmuz ayında Mersin'in Mut ilçesinde dünyaya gelir. Cumhuriyet İlkokulunda başlayan okul hayatı, tarihî Mut Kalesi müştemilatı içindeki Mut Ortaokulunda devam eder. Ortaokuldan sonra Lise tahsilini yapmak üzere İstanbul'a gider. 1987'de Haydarpaşa Lisesinden mezun olur. Aynı yıl, mühendis olma

\footnotetext{
* Müfettiş; Yükseköğretim Kurulu Başkanlığı, sahharun@hotmail.com.
} 


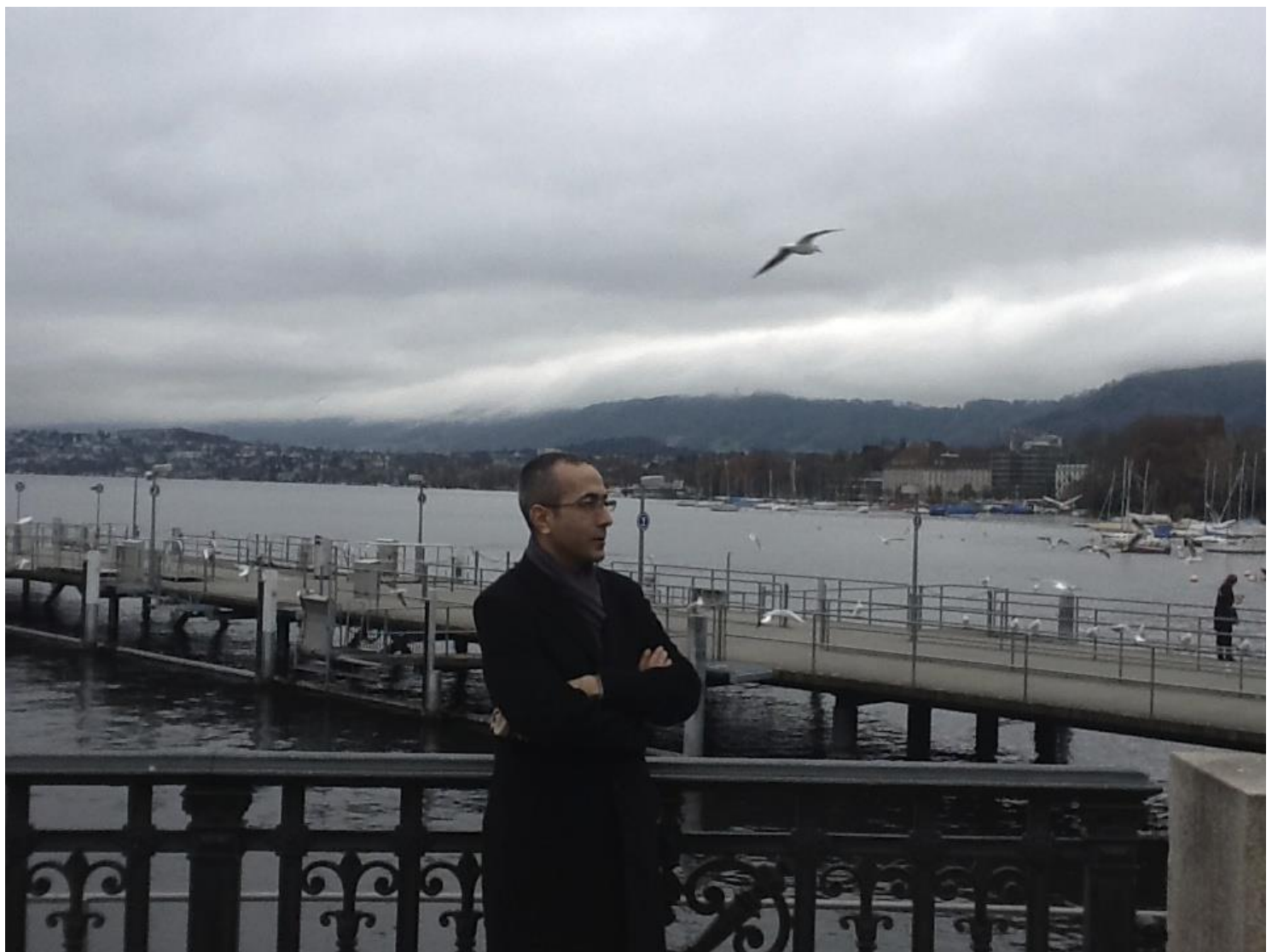

gayesiyle girdiği üniversite imtihanında, İstanbul Üniversitesi Diş Hekimliği Fakültesini kazanır. Lise tahsili ile başlayan İstanbul hayatı hâlen diş hekimi ve yayıncı olarak devam etmektedir.

Mut'un tanınmış, saygın bir ailesine mensup olan Bülent Manav'ın iki dedesi kardeştir. Yani annesi Muhsine Hanım ile babası Yaşar Ali Bey amca çocuklarıdır.

Osman Bülent Manav'ın büyük dedesi Ali Manav, 14 yaşında bir ayakkabıcı "tığ"1 ile Ermenek'ten Mut'a gelmiş, ayakkabı tamirciliği ile uğraşmış, nişanlandıktan sonra askere gitmiş ve 11 sene askerlik yapmıştır. İnsan sözcügünün yanına en çok yakışan kavram işaretlerinden biri "vefa"dır (Alyılmaz, 2015) sözüne bir numunelik teşkil edecek şekilde, onu askerlik süresince bekleyen, vefalı nişanlısı ile askerlik dönüşünde ihtişamlı bir düğün yaparak evlenmiştir. Evlendikten sonra değişik alanlarda esnaflık yapmış, zamanla zengin ve itibarlı olmuş ve Mut havalisinin en saygın esnaflarından biri olarak, memleketine ve insanına emek vermiş, gönül dostu birisidir.

Prof. Dr. Mehmet Kaplan Tip Tahlilleri isimli kitabında "ahi tipi" için "Çalışmaktan maksat, para kazanmak ve biriktirmek değil, hem kendi geçimini temin etmek hem de başkalarına yardımdır." der. Ali Manav'ın hayatı "ahi tipi”ni çağrıştır. O -tam bir fütüvvet ehli gibi- Mut'ta bulunan esnafların birçoğunun yetişmesinde emeği olmuştur. Ali Manav ismi 
bugün hâlâ, Mut, Ermenek, Karaman'da “Manav Koca” olarak saygı ve minnettarlıkla söz edilen bir isimdir.

Osman Bülent Manav, "Manav Koca” şiirinde büyük dedesi Ali Manav’1 söyle anlatmaktadır.

Mut çukurunda ona

Manav Koca derlerdi

Ve bütün Mut severdi.

Biten günün sonunda

İki elinde iki

Sepet, çıkagelirdi.

Akşamüstü yoluna

Dizilince çocuklar

Sevinirdi ihtiyar.

Hem de sevindirirdi

Onlara sepetinden

Hediyeler verirdi.

Nasibi yoktu kinden

Sevdi, sevildi, gitti... (Musandıra, s. 18)

Osman Bülent Manav'ın diğer dedesi "Manav Amca" adıyla maruf Mehmet Manav'dır. Mehmet Manav, 1910 yılında dünyaya gelir. Anne karnında 3 aylık iken babası vefat eder, yetim olarak doğar ve büyür.

İlkokulu, Mut'ta ticaretle meşgul olan ağabeyi Ali Manav'ın yanında okuyan Mehmet Manav, yine aynı ağabeyinin yanında ticaret yapmaya başlar, askerlik öncesi sıtma hastalığına yakalanır. Doktor kendisine yayla havasına ihtiyacı olduğunu, bir müddet Ermenek'e giderek, annesinin yanında istirahat etmesini tavsiye eder. O tarihte, annesi ikinci eşi olan Fehmi Efendi'yle evlidir. Eski bir müderris olan Fehmi Efendi, Mehmet Manav'a hem İslami bilgiler aktarır hem de dinî hassasiyet kazanması için telkinlerde bulunur.

Ermenek'te sıhhatine kavuşan Mehmet Manav, Fehmi Efendi'den etkilenerek dinî vecibeleri yerine getirmeye başlar. Mut'a döndükten sonra bütün faizli alacaklarını siler. Bu tarihten sonra bir derviş edasıyla, ikbal kaygısı taşımadan yaşamaya gayret eder. 
1943 senesinde, emekli bir subay olan Mevlüt Doğan (Eski Diyanet İşleri Başkanı Lütfi Doğan'ın babası) vasıtasıyla İstanbul'da Silistreli Süleyman Efendi ile tanışır. Bu tanışma, ona farklı bir dünyanın kapılarını aralar. 33 yaşına gelmiş olmasına aldırmadan, memleketindeki ticari işlerini bir kenara bırakarak Silistreli Süleyman Efendi'ye talebe olur. Mehmet Manav, vefatına kadar geçen 50 seneyi Silistreli Süleyman Hilmi Tunahan'ın rehberliğinde onun usulünü takip ederek Kur'an Kurslarına hizmet ederek geçirir.

Mehmet Manav, 1993 yılında damadı Ömer Ali Keskin'in daveti üzerine Bolu'ya giderek civarın il-ilçelerini dolaşır, Kur'an Kursu talebelerine sohbetlerde bulunur. Bu amaçla çıktığı seyahatlerden birinde trafik kazası geçirir. Bir bacağı kırılır, ameliyat için verilen narkozun etkisinden kurtulamayarak 13 Aralık 1993 günü vefat eder.

Mehmet Manav ismi, bugün hâlâ, bilhassa Konya, Mersin, Antalya, Bolu illerinde "Manav Amca" olarak yaşamakta, hayat hikâyesi ve kıssaları dost meclislerinde anlatılmaya devam etmektedir.

Osman Bülent Manav'ın hayatında önemli bir yere sahip olan "Küçük Dede” Mehmet Manav'ın ölümü üzerine şairin yazdığı şu dizeler bize Mehmet Manav’ı anlatmaktadır.

\section{Bolu Dağlarında Açar Çiçekler}

Bolu dağlarında açan çiçekler,

Her baharda zikre durmaz misınız?

Dedem siz yokken de dağları bekler,

Bahar bitti diye görmez misiniz?

Çamyayla toprağı çam kokar bütün

Ve Bolu Dağı'nı kuşatır hüzün...

Örtün üzerini, sık1ca örtün,

Siz üşüyenleri sarmaz mısınız?

Rabbine gidiyor Mehmet Efendi,

İltifat eylesin En Büyük Nebi,

Şeyhine kavuşan müridler gibi,

Yürürken koluna girmez misiniz? (Yarpız Kokulu Şiirler, s. 18)

\section{Osman İsminin Verilmesi}

Mehmet Manav, Silifke'nin Mara kasabasında yerleşik bir ailesinin kızı olan Hazel Hanım'la 1935/36'da evlenir. Hazel Hanım, Erzurum'dan, Rus-Ermeni mezaliminden kaçarak, 2 y1l süren ve sefalet içinde geçen bir konargöçerlikten sonra, buraya gelip yerleşmiş bir ailenin 
kızıdır. Mehmet Manav'ın Hazel Hanım'dan 3 kızı ve 4 de oğlu doğmuştur: Muhsin, Muhsine, Ali, Emine, Mehmet, Ayşe, Süleyman.

Osman Bülent Manav doğduğunda babası Yaşar Ali Bey çocuğuna Bülent ismini koyar. Anneanne Hazel Hanım: "Benim buna dilim dönmez, ailede de hiç Osman yok, Hz. Osman Efendimiz 'in adı olsun" diyerek Osman isminin verilmesini ister; ama baba nüfus kaydını çoktan Bülent olarak yaptırmıştır.

Hazel Hanım hac farizası için Mekke-i Mükerreme'de bulunduğu sırada, 5 Şubat 1971'de vefat ederek Hz. Hatice'nin de metfun bulunduğu “Cennet'ül Mualla”ya defnedilir. Bu vefat üzerine Bülent Manav'ın adı, Hazel Hanım'ın hatırasına Osman Bülent olarak anılmaya başlar. Bugün şairin ismi yakın çevresinde, arkadaşları arasında, kitaplarında, yazılarında hep Osman Bülent Manav olarak geçmektedir.

\section{Osman Bülent Manav'ın Yayıncılık Hayatı}

Osman Bülent Manav, fakültesi hayatının ikinci senesinde sınıfta kalır. Bu sene kaybı çocukluk hayali olan "şairlik" ve "yayıncılık" hayatına adım atmasına zemin hazırlar. Bülent Manav'ın ilk yayıncılık denemesi, 1988 yılında birkaç arkadaşıyla birlikte çıkardığı, fotokopi yoluyla çoğaltılan ve ömrü sadece 4 sayı süren Refleks dergisidir. Refleks'te, çeşitli yazılarının yanı sıra şiirleri de yayımlanmıştır.

1989 yılında bir kaç arkadaşıyla birlikte temellerini attığı Dişhekimliği Dergisi'nin ilk sayıs11990 yılında yayımlanır. Bugün itibarıyla 25. yaşını dolduran Dişhekimliği Dergisi, hâlâ, düzenli olarak yayın hayatına devam etmektedir.

1991-1994 y1lları arasında yayımlanan Tepe Edebiyat dergisi ile 2000-2003 arasında okuyucuyla buluşan Başka Istanbul adlı haftalık şehir gazetesi, Bülent Manav'ın kültür ve edebiyat yayıncılığg hayatında iki önemli dönemi ifade eder. Osman Bülent Manav her iki mevkutenin de Genel Yayın Yönetmenliği görevini yürütmüştür.

Kurucusu, ortağ1 ve yöneticisi olduğu Vestiyer Yayın Grubu, ülkemizde profesyonel dental yayıncılığın öncüsü olarak önemli bir yere sahiptir. Çeyrek asrı geride bırakan Dişhekimliği Dergisi’nin yanı sıra, Türk Dişhekimliği Dergisi, Estetik ve İmplant, DentalTribune Türkiye, Roots, Dental Labor Türkiye, PNV gibi ulusal ve uluslararası birçok derginin de yayıncısıdır. Yine diş hekimliği sahasında kimi tercüme, kimi telif olmak üzere pek çok kitap da Vestiyer Yayın Grubu tarafindan yayınlanmaktadır.

Bülent Manav, 2005 yılında, Vestiyer Yayın Grubu bünyesinde yeni bir adım atarak "Vesta"y1 kurar. Vesta, "Vestiyer"in ilk dört ve "Akademi”nin ilk harfinin bir araya gelmesiyle 
oluşturulan bir markadır. Bu yeni yapılanma ile mezuniyet sonrası 'sürekli diş hekimliği eğitimi’ konusunda dünya standardında mesleki kurslar düzenlemeyi amaçlamaktadır. İstanbul başta olmak üzere Viyana, Londra, Los Angeles, Ankara, İzmir, Mersin, Lefkoşa, Zürih, Stuttgart gibi yurt içi ve yut dışındaki birçok şehirde söz konusu kurslar icra edilmekte olup, bu sayede binlerce hekim bilgi ve becerilerini güncelleme ve güçlendirme imkânı bulmaktadır.

2002'den beri düzenlenen ve Türkiye'nin diş hekimliği alanındaki en geniş katılımlı 3 kongresinden biri olan "Dental İstanbul”un kurucusu ve Düzenleme Komitesi Başkanı olan Bülent Manav, Boğaziçi Dişhekimliği Derneği'nde de Yönetim Kurulu Başkanı sıfatıyla çalışmalarını devam ettirmektedir.

\section{Osman Bülent Manav'ın}

\section{Eserleri}

Tepe Edebiyat, Kültür Dünyası, Türk Edebiyatı, Genç Akademi, Başka İstanbul, Boğaziçi Bülteni, Dişhekimliği Dergisi vb. mecmualarda şiir, hikâye, deneme ve makaleleri yayımlanan Osman Bülent Manav'ın en çok ilgilendiği edebî tür şiirdir.

2005 Tarih Düşünce ve Dergisi'ne verdiği bir mülakatta şiirle olan tanışıklığını şöyle anlatmaktadır:

Benim şansım, ailemizde şairin

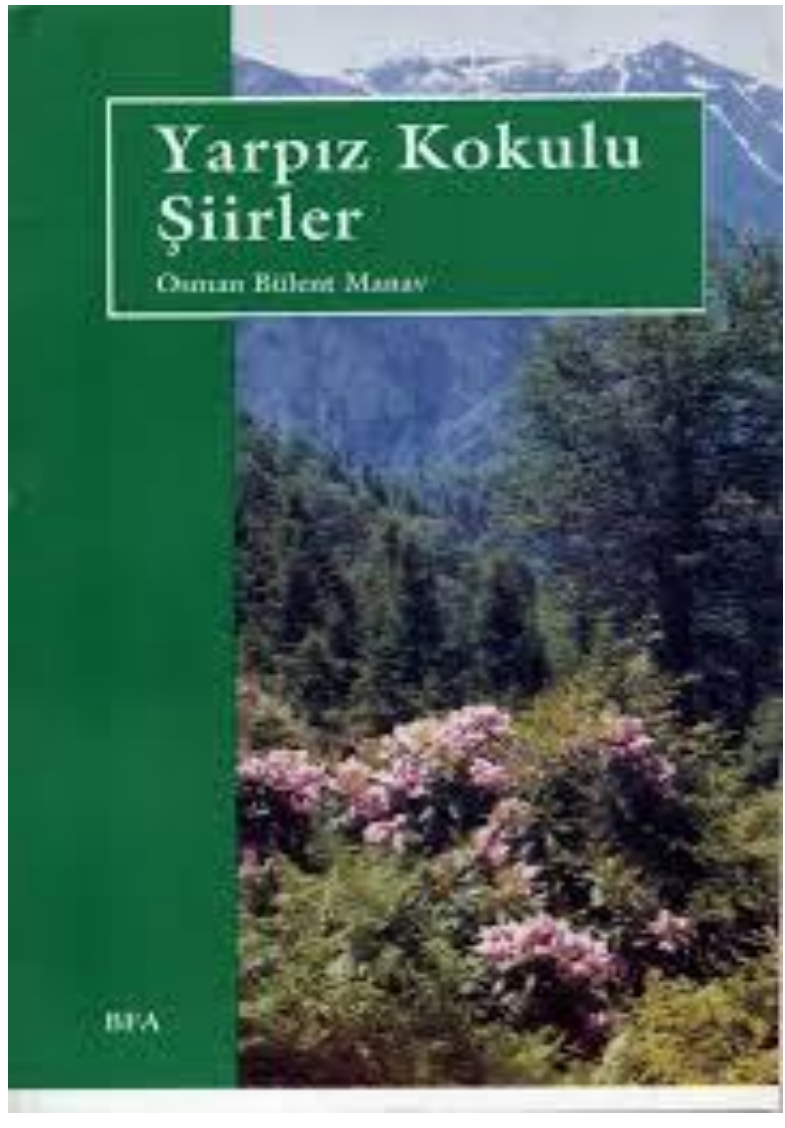
bulunmayıp şiir okuyucularının bulunmasıydı galiba. Annem, Cahit Sıtkı'nın Otuz Beş Yaş Şiiri başta olmak üzere birçok şiiri ezbere bilir ve zaman zaman bize okurdu. Büyük ağabeyim, henüz okula başlamadan önce bana bir sürü şiir ezberletmişti. Babam ise iflah olmaz bir İstiklal Marşı ve Harbiye Marşı fanatiğiydi ve ikisini de bana ezberletmişti. Dedemin ise bir cep defteri vardı. Hoşuna giden şiirleri, beyitleri oraya yazardı. Ailecek otururken keyfi yerindeyse o defteri çıkarır, bize şiirler okurdu (s. 54-58) 
Osman Bülent Manav'ın iki şiir kitabı bulunuyor: Yarpız Kokulu Şiirler ve Musandıra.

1994 yılında BFA Yayıncılık tarafından yayınlanan Yarpız Kokulu Şiirler şairin ilk kitabıdır. "Beyaz Zambak", "Karanfill", "Kırçiçekleri”, "Kekik" başlıklı 4 bölümden oluşan kitap, 62 sayfadan ibaret olup şairin 38 şiirini ihtiva etmektedir.

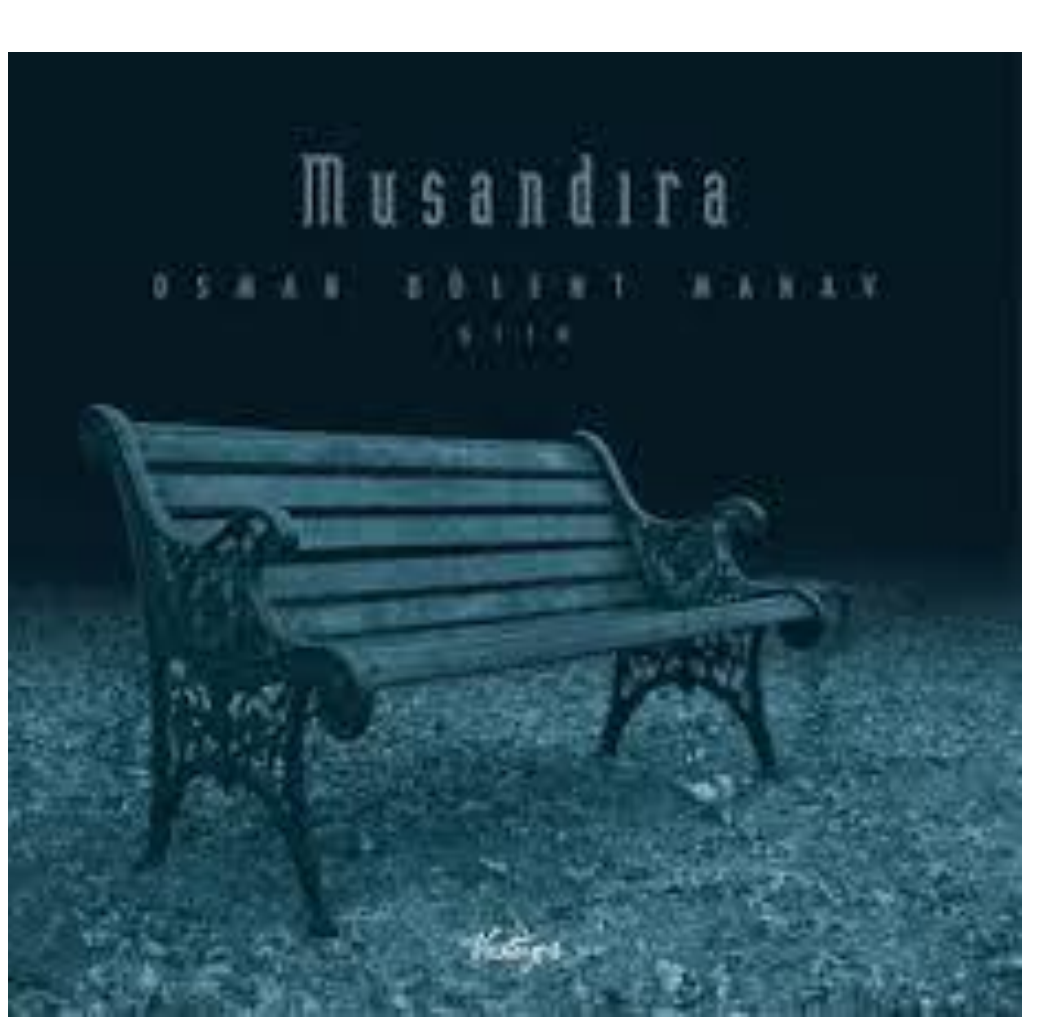

$2004 \quad$ yılında
kurucusu olduğu Vestiyer
Yayın Grubu tarafından
basılan Musandıra şairin
bir diğer şiir kitabıdır.
"Çocukluğumuzla giden”,
"Yaşarken", "Kalbimiz
şehrimizdir", "Son bahar
şiirleri” $\quad$ başlıklı 4
bölümden oluşan kitap 72
sayfadan ibaret olup şairin
38 şiirini ihtiva etmektedir.
Osman Bülent
Manav'ın iki kitabında ver
almayan, çeşitli dergilerde

ve web sayfalarında yayımlanmış birçok şiiri daha mevcuttur; ancak, bu makalemizde sadece kitaplarında yer alan 76 şiir değerlendirmeye alınmıştır.

\section{Osman Bülent Manav'ın Edebî Kişiliği ve Sanatı}

\section{1. Şiirinin Şekil Özellikleri:}

Osman Bülent Manav'ın şiirleri nazım birimi açısından çeşitlilik göstermektedir. Onun şiirlerini, geleneksel Türk şiiri nazım birimleri etrafında sınıflandırmak zordur. Biz bu çalışmada hane sayısı, hece sayısı, mısra sayısına dayalı bir değerlendirme yapmayı tercih ettik.

Şairin yayımlanmış şiir kitaplarında yer alan 76 şiiri incelemeye tabi tutulduğunda hane sayıları şöyledir:

Bir haneden kurulu şiir sayısı: 25 tane,

İki haneden kurulu şiir sayısı: 19 tane,

Üç haneden kurulu şiir sayısı: 10 tane,

Dört haneden kurulu şiirler: 7 tane, 
Beş haneden kurulu şiirler: 8 tane,

Altı haneden kurulu şiirler: 1 tane,

Sekiz haneden kurulu şiirler: 1tane,

Dokuz haneden kurulu şiirler: 1 tane,

On haneden kurulu şiirler: 1 tane,

On üç haneden kurulu şiirler: 2 tane,

On yedi haneden kurulu şiirler: 1 tanedir.

Osman Bülent Manav, iki şiir kitabında yer alan şiirlerin tamamını hece vezni ile yazmıştır. Hece vezninin de umumiyetle $7+7=14$ ve $6+5=11^{\prime}$ li hece ölçüsünü kullanmıştır.

Bin edayla süzülmek/ rüzgârlarla dost olmak,

Ardından sürüklenmek/ hepsi onun şanında...

Hep o, Sahra'da donup/ Sibirya'da kavrulmak...

Bayrağın üstün sırrı/ şehadet nişanında... (Yarpız Kokulu Şiirler s. 30)

Ne gece sükûneti /ne bahar sarhoşluğu

Ne yayla mevsimleri/ ne bâd-1 sabâ kaldı.

Buz edip dondurdular/ gözlerdeki buğuyu;

Yarpız kokulu şiir/ başka bahara kaldı (Yarpız Kokulu Şiirler s. 62).

Nazım birimi olarak 4'lüklerin tercih edildiği şiirlerde abab, cdcd kafiye düzeni; beyit ve bentlerden oluşan nazım şekillerinde aa, bb, cc... ; aa, ba, ca; ab, cb, db......ş̧eklinde kafiye düzeni tercih edilmiştir.

Onlar anlayamaz/ ölmeyi anne,

Dağlar yeşerirken/ mevsim baharken

Hiç ölmemişlerdir/yirmibirinde

Namluya rastlanıp/ yâri düşlerken... (Musandıra, s. 53)

Hisler ki, içimizde, hepsi birer rüzgârdır.

Hepsinin hepsinde bir hikâyesi vardır.

Öfkelenince lodos, gülümseyince meltem,

Köyde şeytan düğünü, karıncalarda mâtem (Musandıra, s.38).

Bent şeklinde yazılan bazı şiirlerde geleneksel kafiye düzeni tercih edilmemekle birlikte, iki mısra kendi içinde kafiyeli, takip eden bir mısra serbest, sonraki iki mısra yine kendi içinde kafiyeli olmak üzere, aa $\mathbf{x}$ bb cc şeklinde kafiyeleyerek şiirde bir ahenk ve düzen oluşturulmaya çalışılmıştır.

Ey benim heyecanım, / umudum, can yoldaşım. 
Yüreğimin sahibi / ve hayat arkadaşım...

Ey benim İstanbul'um / alfabemin ilk harfi

Ve hasretim ve öfkem / ve yirmisekizyaşım,

Deliliğim, utancım / gözbebeğim, sırdaşım...

Kulağımda ilk ezan / kapımda bad-ı sabâ

Ey gönül aydınlığım / ilkbaharım merhaba... (Musandıra, s. 32)

\subsection{Osman Bülent Manav'ın Şiirlerinde İşılediği Temalar}

\subsubsection{Tabiat Teması}

Tabiatın emzirdiği bir çocuk olmak, tabiatın kucağında yaşamak, tekenin rehberliğinde geçit vermez dağları aşarak, bir platoda soluklanmak, hatta "yayla"da doğup "güzle"de ölmek, mübarek bayram günlerinin arifesinde yayladaki kabirleri ziyarete gitmek yarı göçebe yörük hayatının ve bu hayat tarzının mekânlarından biri olan Akdeniz ikliminin tabii neticesidir. Böyle bir hayat tarzının mensubu olan Osman Bülent Manav da çocukluk ve gençlik yıllarında tabiat ile iç içe bir hayat yaşamıştır. Onun çocuğu olduğu coğrafya ile tabii hayat arasına halis ve tam bir ahenk vardır. Mevsimi gelince yaylaya göç etmeyi bir ihtiyaç olarak kabul eden bir toplumun çocuğu olan ve çocukluk hayatının önemli bir kısmını yaylada geçiren şairin şiirlerinde tabiat unsuru mühim bir yere utar.

Osman Bülent Manav, Yarpız Kokulu Şiirler isimli kitabının bölüm başlıklarına hep tabiattan isimler vermiştir: "Beyaz Zambak", "Karanfil”, "Kırçiçekleri”, "Kekik”. Özellikle Kekik (Dağların Kokusu) bölümündeki şiirlerde ve sair birçok şiirinde tabiat ile insan arasındaki munis bir bağ kurar. "Yarpız Kokulu Şiir" adlı çalışmasında bu bağ, "Kaf Dağı Ülkesi’nin Yolu”nun geçtiğì”, “ceviz başlarında anka kuşlarının öttüğü̈”, “şahmaran’ın sarayının kurulduğu", "sadra şifa tütsülü yarpızların yetiştiği”, "masalların can bulduğu”, hayat olduğu, hasılı bir çok güzelliğin yaşandığı bir mekân olarak tasvir edilir:

Yaylayı bilmeyenler, yarpızı da bilmezler,

Bilmezler sadra şifa tütsülü yokuşları...

Kaf Dağı Ülkesi'nin yolu yayladan geçer,

Cevizlerin başında döner anka kuşları...

Gün akşama döndü mü Toros yaylalarında

Çakallar tempo tutar, dellenir kuru poyraz,

Bir gam musallat olur kavakların başına...

Masallar, yaylalarda hayat bulur, can bulur

Uçan halı yayladan başka yerde uçamaz! 
Şahmaran'ın sarayı sarp dağlara kurulur... (Yarpız Kokulu Şiirler, s. 60)

Osman Bülent Manav, insan hâl ve hareketleriyle tabiat arasında bir tenasüp bulunduğu düşüncesiyle insan ahvali ile tabiat arasında bir bağ kurar:

Merhamet yağmurdur, öfke firtına,

Aşkı yalnız dağlar anlayabilir

Ve sabır topraktır coğrafyamızda,

Onunla iksire dönüşür zehir (Musandıra, s. 29).

\subsubsection{Vatan ve Millet Teması}

Şairler mensubu olduğu milletin ve mirasçısı olduğu vatan toprağının sesidirler. Onlara yazma ve söyleme aşk1 veren heyecan tevarüs ettiği kültür hazinelerinde gizlidir. Osman Bülent Manav, "vatan namustur" ilkesinden hareketle çeşitli şiirlerinde vatan ve millet temasını işlemiştir. Onun "Şehidin duası" şiiri Çanakkale Zaferi'den, "Gitmek" şiiri de kızıl elma ülküsünden ve şehitlik mertebesinden ilham ile yazılmıştır. "Son Bahar" ve "Şimdi yol ve gurbet zamanı" şiirleri ise devletimizin otuz yıldır mücadele ettiği güneydoğu meselesini ele almaktadir.

Bir sicak Temmuzda döğmek isterdim

Ve yeniden yazmak Çanakkale'yi, (Musandıra, s. 39.)

Gönlündeki yağmur dinmesin yârim,

Yüreğin hasretsiz kalmasın sakın.

Hayat bu, bilinmez, belki dönerim,

Ben yokken sonbahar gelmesin sakın (Musandıra, s. 51).

Onun şiirlerinde vatan ve millet sevgisi aleni bir hamaset ile karşımıza çıkmaz. Öfkemiz tutuştuğunda, göğsümüzü ateş sardığında bile bu duygular ince bir hissi duyarlılıkla dile getirilir:

$\mathrm{Bu}$ şiir öfkemiz tutuştuğunda

Göğsümüzü saran ateşe dair

Tek kelam etmeden akşam olunca

Ağlayışımızın hikâyesidir... (Musandıra, s. 50)

-.

Yirmi bir yaşında, ahret yolcusu,

Kardeş kurşunuyla devrildi yere

Bir âh eyledi ki, gökler dolusu... 
Ölümü anlattı bilmeyenlere ... (Musandıra, s. 52)

\subsubsection{Dinî, Tasavvufi ve Ahlaki Temalar}

Her milletin kendine has millî, manevi ve ahlaki kıymetleri vardır. Türk milleti tarih sahnesine çıkıp medeniyetler inşa etmeye başladığı günden beri, kendi millî ve manevi hassasiyetlerini ifade eden bir sanat, bir mimari ve bir edebiyat oluşturmuştur. Hususi ile Anadolu'ya hâkim olduğumuz tarihten bu güne kendimize ait değerler çerçevesinde bir dünya kurmaya önem vermişiz. Hükmettiğimiz coğrafyada inşa ettiğimiz mimari, vücuda getirdiğimiz sanat eserleri, şiirimiz, edebiyatımız, yaşayışımız gelenek ve göreneklerimiz, elbiselerimiz, mezar taşlarımız... hep bir millet olduğumuzu hatırlatır. Yahya Kemal Beyatlı, "Koca Mustapaşa" isimli şiirinde bu durumu söyle ifade etmektedir.

Bu muammâyı uzun boylu düşündüm de yine,

Dikkatim hâdisenin vardı derinliklerine;

Bu geniş ülkede, binlerce lâtîf illerde,

Nice yıll, cedlerimiz kökleşerek bir yerde,

Manevî varlığının resmini çizmiş havaya.

Ki bugün karşılaşan benzetiyor rü'yâya.

Osman Bülent Manav, varisi olduğu medeniyetin sadece kimliğini taşımaz; o toprağında yeşerdiği kültürün kişiliğini de taşır. Şairin kitabına da isim olan "Musandıra" isimli birbirini takip dört şiirinde, kaybolmaya yüz tutan medeniyet unsurlarımızın 1stırabı hissedilir. Ona göre bu değerler "televizyon ekranında aile içi sırları döküp saçmak için sıraya giren, kamera önünde tanışan, sevişen, evlenen kavga eden ve yine kamera önünde boşanan insanların dünyasında kendine yer bulması imkansızdı". "Mahrem kuytumuza düşen ışık, musandıranın sonu oldu" (Musandira, s. 5).

Masalsız büyüyor şimdi çocuklar,

Ne konuşan çiçek, ne ağlayan kuş...

Hayal ülkesinde susunca rüzgar,

Anka uçup gitmiş, devler uyumuş...

Oysa biz tıkayıp kulağımızı,

Kevser' in sesini duyabilirdik...

Hışımla camlara vuran poyrazı

Söze kalbetmeyi bir biz bilirdik...

Aşkın ifadesi gözyaşlarıydı,

Belki de mektubun ucunu yakmak... 
İstinye koyunda yaz akşamları,

Sular sararınca semaya bakmak...

Mevsimler zamansız çıkmazken yola,

Sevgi gönüldeydi, hem en derinde...

Hep ikindi vakti gelirdi leyla,

Bütün bir İstanbul, eteklerinde...

Gençken, yürekliyken, kor kor yanarken

Kurduğumuz hayal içre gülendam

Bir özge çiçekti, güneş sönerken,

Onun kadar güzel inmezdi akşam...

Ağla Alaaddin, kırıldı lamba,

Her parçası ayrı alıcı buldu,

İyi para etti haraç mezatta,

Cinlerin tahtına bilim kuruldu... (Musandıra, s. 12-13)

Ama bütün sapmalara, kırılmalara ve yozlaşmalara rağmen, bizim mührümüzü cemiyet nizamımızı ifade eden bir umut da taşır. Şair, bir esenlik ve ebediyet arzusuyla sessizce gelen mesajı, sehl-i mümteni diyebileceğimiz sade ama engin derinlik ile kulaklarımıza fısıldar, umutlarımız yeşerir:

Eski bir ahbabın selâmı gibi

Cemreler içinde gelince bahar

Başımızda rüzgâr, gölümüzde yâr

Hani gökyüzünü kuşatır da

Gül kokan yağmurlar beklerdik hani

Eski bir ahbabın selâmı gibi

Cemreler içinde gelince bahar... (Musandıra, s. 20)

\subsubsection{Aş̧ ve Gurbet Teması}

İnsanın insana, mahlukata, tabiata, eşyaya veya yaratıcısına olan sevgisi, sevdası, aşkı her zaman sanatın konusu olmuştur. Sevgi unsuru olmadan, bu sevgiye sadakat ve vefa göstermeden edebiyat vücuda getirmek kabil olmasa gerek.

Bizim kültür ve edebiyatımızda sevgi ve aşk; elemi, acıyı, belki de daha yerinde bir kelimeyle melâli de beraberinde getirir. Sevilenin verdiği acı ve elem de sevenin nazarında makbuldür. Âşıklar, sevgilinin sevgisinden lezzet aldıkları gibi mihnetlerinden de haz duyarlar. 
"Mutlak güzel olan Allah bir kimseye mihnet murat etmişse o mihnet Hakk'1n nimetidir" anlayışı sevgiden doğan melali makbul kılmıştır. Osman Bülent Manav'nın şiirlerindeki aşk ve gurbet unsurunu bu çerçevede değerlendirilebilir. O, "aşk-acı", "yakın-uzak", "merhaba-elveda" kelimeleriyle kurduğu tezat ile aşk ve gurbeti bir arada işler:

Aşk demek biraz da acı çekmektir.

Aşk insan içindir insan aşk için

En yakın, en uzak, en ulaşılmaz,

Hayata bir ömür mesafesinde...

Ve aşk kalpten kalbe giden yolları

Haraca bağlayan yaşlı harami;

Asırlar demlenir yorgun sesinde...

Düğüm düğüm ateş boğazımızda...

Birkaç ağlamaklı sevda mısra süzülür

Merhaba beklerken gelir elveda

Aşk hep mevsimsiz hep sessiz ölür (Musandıra, s. 17)

Bazen de kavruk bir Anadolu delikanlısının yaşadığı, yürekte nihan olan aşkı, aynı mahremiyetle dile getirir:

Masmavi yemyeşil ve kıpkırmızı

Duygular büyütüp yüreğimizde

Köz gibi usulca tükeniriz de

Kimse anlamaz yandığımızı... (Musandıra s. 28)

Osman Bülent Manav'ın şiirlerinde genellikle aşk teması gurbet ve ayrılığın melali ile ifade edilir. Ancak bazen yaşama sevinci ve lirik duygularla da karşımıza çıkar:

Ey benim heyecanım, umudum can yoldaşım

Yüreğimin sahibi ve hayat arkadaşım...

Kulağım da ilk ezan kapımda bâd-ı saba

Ey gönül aydınlığım ilkbaharım merhaba... (Musandıra, s. 32)

\subsection{Osman Bülent Manav'ın Şiirlerinde Mekân Unsuru}

Osman Bülent Manav, icra ettiği meslek gereği, Türkiye ve Dünya'da pek çok şehre sık seyahatlerde bulunmasına rağmen, şiirlerinde sadece iki mekânın baskın tesiri altındadır. Biri doğup büyüdüğ̈ ve 14 yaşına kadar yaşadığı Toroslar, yani "yayla", diğeri ise İstanbul'dur.

Yaylayı bilmeyenler, yarpızı da bilmezler,

Bilmezler sadra şifa tütsülü yokuşları... 
Kaf Dağı Ülkesi'nin yolu yayladan geçer,

Cevizlerin başında döner ankâ kuşları

İstanbul diyorum yani kalbimiz

Yani hayâlimiz yani kendimiz... (Yarpız Kokulu Şiirler, s. 60)

Bu iki mekânın tesiri bazen doğrudan, bazen dolaylı olarak birçok şiirde hissedilir.

Şimdi bağlar târümâr ve gökyüzü bulutlu,

Fec-i sâdıkbezminde uyanmaz oldu ufuk...

Aratmazdı yaylanın akşamı İstanbul'u,

Akşamla kan rengine boyanmaz oldu ufuk... (Yarpız Kokulu Şiirler, s. 61)

Şair, "Gökberk Kışlası", "Bolu dağında açan çiçekler" gibi bazı şiirlerinde farklı mekânlardan söz etmektedir. Bu mekânlardan muayyen bir durumu anlatmak için bahsedilmiş olup şairin sanatı üzerinde tesiri hissedilmez.

Gökberk Kışlasına askerler iner,

Soylu bir merhamet Karadeniz'e.

Gözpınarlarımız nemliyse eğer,

Ayrılık değmiştir yüreğimize... (Musandıra, s. 30)

\section{Osman Bülent Manav'ın Dil ve Üslubu}

Osman Bülent Manav şiirlerini genelde standart Türkiye Türkçesi ile yazmıştır; ama şuurlu bir şekilde Mut yöresinde kullanılan, harkıt (eski, kırık, horkut, umacı, öcü), kağşamış (eskimiş, yıkılmaya yüz tutmuş), gibi bazı mahalli kelimeler kullanılmıştır.

Kağşamış evlerin cumbalarından

Sokağı gözleyen çiçekler gibi

Gerçeği hayalle kanatlandıran

Çocuklardır şehrin asıl sahibi... (Musandıra, s. 11)

Hem eski eşya hem masal kitabı,

Sini, Kevgir, maltız, hepsi burada,

Sabırtaşı, Harkıt, Lokman kitabı,

Hayâl ve hakikat musandırada... (Musandıra, s. 12)

Şair, şiirlerinde sık sık "Anka" "Ahfeş’in Keçisi”, "Alaaddin” "Kafdağı ülkesi” "Şahmaran'ın sarayı" "Ebu Zerr”, "tebyin-i garaz”, “yekûn-u içtima”...gibi kelimeleri ve "mektubun ucunu yakmak", "ağaçtan öteye giden yol"... gibi deyimleri kullanarak telmihlerde bulunur. Diğer taraftan "turfe”, "şehrayin”, “meclis-i yaran”, "haraç- mezat”, "harcıâlem”... gibi kelimeleri kullanmaya özen göstermiştir. 
Gölgeler uzayıp gün kısaldıkça

İlim kapısını terketti âlem,

Sadece Ahfeş'in keçisi kaldı,

Geçkin meyve gibi boşaldı ülkem. (Musandıra, s. 19)

Burası bir turfe dükkân-1 hikem,

Raflarda rengârenk umutlarımız,

Kimi harcıâlem, kimiyse mahrem,

Bütün hiçliğimiz, bütün varımız... (Musandıra, s. 12)

Şiirlerinde kolay ve sade söyleyişlerle derin tesirler uyandırma gayreti ile birlikte tek cümlelik kıtalar, hatta şiirleri vardır. Şiirlerdeki bazı kıtalar, mana ve ifade şekli bakımından kendi içinde, gramer olarak olmasa bile anlam olarak, tek cümleden ibaret dörtlüklere rastlamak mümkündür.

$\mathrm{Bu}$ şiir öfkemiz tutuştuğunda

Göğsümüzü saran ateşe dair

Tek kelâm etmeden akşam olunca

Ağlayışımızın hikâyesidir (Musandıra, s. 50).

\section{Sonuç}

Osman Bülent Manav, edebiyata, bilhassa şiire gönül vermiş, bu sahada iki şiir kitabı neşretmiş bir hekimdir. Türk ahlak kaidelerine, dinî, millî değerlere bağlılığı ile bilinen ve yaşadığ cemiyet içinde saygın bir yeri olan ailesinin şiire olan ilgisi, onun yetişmesinde etkili olmuştur.

Osman Bülent Manav'ın şiirleri nazım birimi açısından çeşitlilik göstermektedir. Onun şiirlerini, geleneksel Türk şiiri nazım birimleri etrafında sınıflandırmak zordur. İncelemeye esas iki şiir kitabında yer alan şiirlerin tamamını hece vezni ile yazmıştır. Hece vezninin de umumiyetle $7+7=14$ ve $6+5=11$ 'li hece ölçüsünü kullanmıştır.

Osman Bülent Manav, insan hâl ve hareketleriyle tabiat arasında bir tenasüp bulunduğu düşüncesiyle insan ahvali ile tabiat arasında kuvvetli bir bağ kurar. Ona göre "vatan namustur"; ama vatan ve millet sevgisi aleni bir hamaset ile değil, ince bir hissî duyarlılıkla karşımıza çıkar.

Sade yaşantısıyla varisi olduğu medeniyetin kimliğini ve kişiliğini taşır. Bu cümleden olmak üzere şiirlerinde, kaybolmaya yüz tutan medeniyet unsurlarımızın 1stırabı hissedilir. Onun şiirleri iki mekânın baskın tesiri altındadır: Biri doğup büyüdüğü ve 14 yaşına kadar yaşadığı Toroslar, yani “yayla”, diğeri ise İstanbul'dur. 
Osman Bülent Manav şiirlerini genelde standart Türkiye Türkçesi ile yazmıştır. Onun şiirlerde yanlış kullanılan bir kelimeye veya imla hatalarına rastlanmaz, ama şuurlu bir şekilde bazı mahalli kelimeleri de kullanmıştır. Şair, şiirlerinde sık sık telmihlerde bulunur. Böylelikle şiirlerin anlam derinliği kazanmasına önem verir.

\section{Kaynaklar}

ALYILMAZ, C. (2014). 90. Yaşı Dolayısıyla Prof. Dr. Meşedihanım Sadullahgızı Ne'met. Uluslararası Türkçe Edebiyat Kültür Eğitim Dergisi, 3(4), 183-189.

DİLÇìN, C. (1995). Örneklerle Türk Şiir Bilgisi. Ankara: Türk Dil Kurumu Yayınları.

KAPLAN, M. (1991). Türk Edebiyatı Üzerine Araştırmalar Tip Tahlilleri. İstanbul: Dergâh Yayınları.

Türk Dil Kurumu (2005). Türkçe Sözlük. Ankara: TDK Yayınları.

Türk Dil Kurumu (2009). Derleme Sözlüğ̈̈. Ankara: TDK Yayınları. 